\title{
Effect of Replacing Dietary Maize with Graded Amounts of Cane-molasses on Lamb Performance
}

\author{
A.M. Wl-Serafy, H.M. Khathab, H.S. Soliman and
M.A. WI-A.shry \\ Faculty of Agric., Ain Shams Univ., Egypt.
}

\begin{abstract}
levels of calch on lamb performance of induding different levels of cane molasses in rations for fattening Ossimi lambs
was studied.

Three expermental rakions were used in this experiment. In fations is and C, molasses were included mo masses, while and $26 \%$ in the DM.

rences in growth xates or theed there were no signilicant diffethe three experimental rations. efficiency between lambs given of moiasses, however, grew slower Lamb given the highest level efficiently than growns givew slower and utilized their diets less Apparent digestibill given $0 \%$ or $14 \%$ molasses. creased with ircreasing level of DM, OM, CW, N and IE, denitade of this reduction molasses in the diet. The mag the highest level of Por $\mathrm{C}$. $N$ and $\mathbb{N E}$ digestibllities. It was also more pronounced the level of molastiblities.

on dressing percentage appears to have no signimicant effect The resulis are dive and slaughter data.

bolism of dists contsonsed in relation to digestion and moto post rominaly.

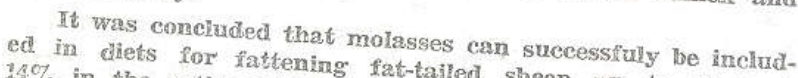
$21 \%$ in the ration DN.
\end{abstract}

Sugar-cane molasses reoresent a valuable by-product of sugarrates. The industry because of its high content of available carbohydis likely to increace with as an energy supplement to animal feeds from sugar beet in the area new expansion in sugar production

Although meny

use of cane-molasses in meriments have been directed to study the (Clark et al. ,1973; Losada et al, 1973 dairy and fattening cattle little information is available on 1973 and Huektas et al., 1975). fattening fat-tailed lambs.

The present experiment was, therefore, carried out to study the effect on lamb performance of including different levels of cane-molasses in rations for fattening Ossimi lambs. 
Material and $M$ et hods

Animals

Nineteen male Ossimi lambs of about 3-4 months of age (16 $\mathrm{kg}$ live weight) were used in this study. They were distributed wccording to their body weights to three groups and within groups assigned at random to receive one of three experimental rations. Groups 1 and 2 contained 6 lambs each while group 3 contained 7 lambs. Another six male lambs of about $40 \mathrm{~kg}$ live weight on average, were involved in digesibility trials ( 2 per treatmont) to determine the effect of level of molasses on apparent digestibility of nutrients.

Diets

Three expeximental rations were formulated to supply the energy and protein allowances recommended by Tommi (1963) for growing and fattening lambs. Ration A served as control and consisted mainly of Co-op feed mixture*, wheat bran and ground maize. In mations $\mathrm{B}$ and $\mathrm{C}$, half $(50 \%)$ and all (100\%) of dietary maize was replaced iso-calorically with cane molesses on the assumption that the SV of molasses is half of that of maire (Abou Raya, 1976). Clover hay was used as the sole source of roughage and offered to the experimental animals at the rate of $400 \mathrm{~g} / \mathrm{day}$.

Molasses was included in the diets by simple mixing with wheat bran, ground maize and the Co-op feed just before feeding. The level of molasses in diets $B$ and $C$ represents about 14 and 26\% on dry matter basis. All diets were swpplemented with vitamin and mineral mixtures. The composition of the three experimental diets is presented in Table 1. The lambs were individually fed and the diets were offered to the animals in two equal portions at 08.00 and 16.00. The experiment lasted for 147 days during which live weights and food intakes were recorded at weekly intervals. The first 15 days of the experiment were considered as preliminary period.

At the end of the experiment, all animals were slaughtered after being fasted for $15 \mathrm{hr}$. Weights of carcasses, pelts, heads, legs, ribs (9ih, 10th and 11th), hearts, lungs, kidneys, spleens,

Co-op feed mixture contained; cotton seed cake $(64 \%)$, rice bean $(20 \%)$, wheat bran $(10 \%)$, molasses $(3 \%)$, limestone $(2 \%)$ and sodium chloride $(1 \%)$.

Egypt. J. Anim. Prod. 21, No. 2 (1981) 
TABLE 1. Composition of the three experimental rations containing graded amounts of molasses in place of dietrary maize.

\begin{tabular}{|c|c|c|c|}
\hline \multicolumn{4}{|c|}{ atter) } \\
\hline Ingredients: & Ration $A$ & Ration B & Bation C \\
\hline Wheat bran & 870.2 & 160.6 & 152.1 \\
\hline co-op feed & 308.6 & 291.2 & 275.7 \\
\hline Ground maize & 174.0 & 82.1 & - \\
\hline Wolasses & - & 138.3 & 262.0 \\
\hline Clover hay & 347.2 & 327.8 & 310.2 \\
\hline \multicolumn{4}{|c|}{ Chemical conposition, \% Dasis: } \\
\hline Dry matter & 90.5 & 88.3 & 86.3 \\
\hline Crude protein & 17.0 & 15.4 & 14.0 \\
\hline Crude fiber & 15.7 & 94.7 & 13.8 \\
\hline Ether Bxtract & .4 .1 & 3.6 & 3.1 \\
\hline 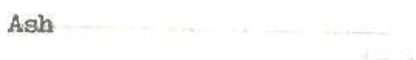 & 10.8 & 12.2 & 13.4 \\
\hline Soluble carbohyarates (NFg) & 52.4 & 54.1 & 55.7 \\
\hline
\end{tabular}

livers, four compartments of the stomach, small and large intestines (full and empty) were recorded. The weights of each of these parts as percentages of body weights were also calculated. Dressing percentage was calculated as the ratio between hot carcass weight including the tail relative to fasting live weight.

Chemical analysis

Representative samples of dietary ingredients were analyzed for dry matter (DM), Ash, nitrogen (N), Ether extract (EE) and crude fibers (CF) according to the O.A.A.C. (1970). Soluble carbohydrates were determined by difference (NFE).

\section{Statistical analysis}

Data for daily live weight gain, gross efficiency ( $\mathrm{g}$ gain $/ 100 \mathrm{~g}$ SV or TDN eaten) and carcass characteristics were subjected to analysis of variance for unequal numbers according to Snedecor and Cochran (1967). 
All animals (except one) remained healthy and completed the experiment. One lamb receiving diet $B$ died during the trial. Post-mortem examination showed that pulpy kidney wrs the main cause of death, which was not related to treatment. The fact that no death losses occurred in the group of lambs given the highest level of molasses (diet C) may further support the above conclusion. All animals consumed their diets with no palatability problems.

Lamb performance

Mean values with their standard error (SE) for daily live weight gains, gross efficiencies and food intakes are presented in Table 2,

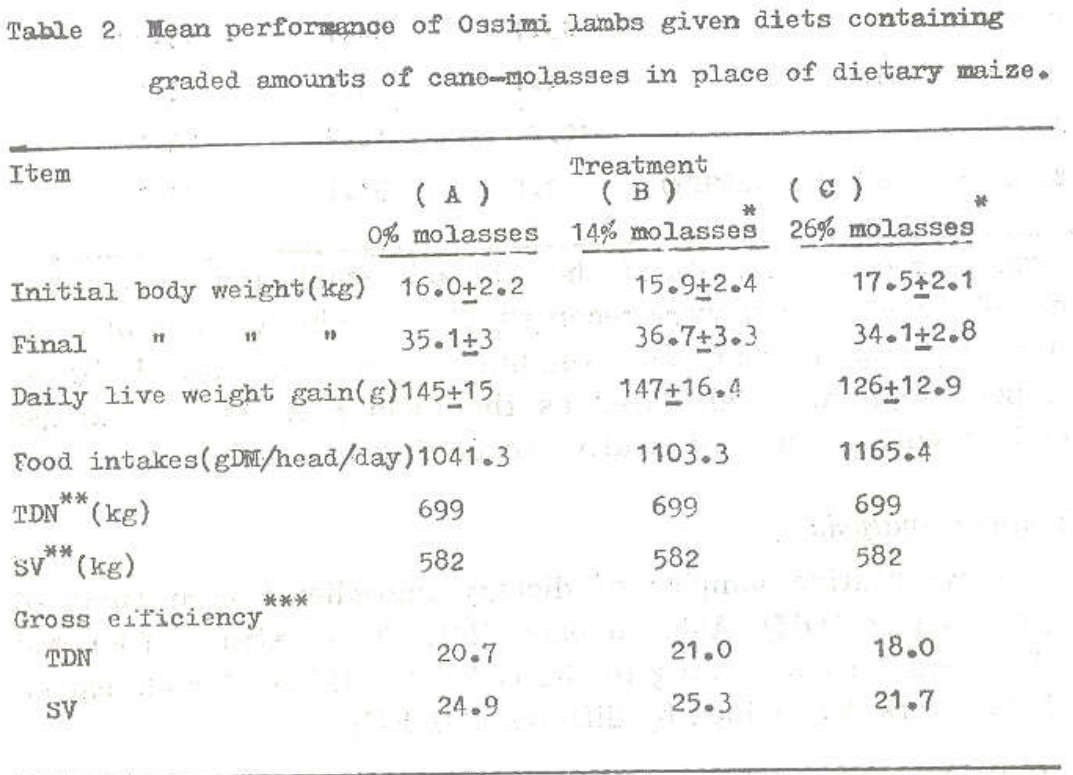

* As percentage of dietary maize(on Drit basis).

**Calculated on the basis of the values published in Abou-Raya(1967). *** Ef gain/100 E SV. or TDN. intake.

Egypt. J. Anim. Prod. 21, No. 2 (1981) 
Analysis of variance showed no significant differences in daily gains or gross efficiencies between the three groups of lambs. However, lambs given the highest level of molasses (26\%) grew at a slower rate and were less efficient in their diets into live weight in comparison with the groups of lambs given either $0 \%$ or $14 \%$ molasses.

\section{Apparent digestibility of nutrients}

Mean values for apparent digestibility of DM, OM, N, EE, CF and soluble carbohydrates are presented in Table 3. The replacement of maize with molasses in diets for growing lambs appears to depress apparent digestibility of all nutrients: The magnitude of this depression was highest for lambs maintained on the highest level of molasses. The most pronounced reduction in apparent digestibility was that of $\mathrm{CF}, \mathrm{N}$ and $\mathrm{EE}$. Only the reduction in $\mathrm{CF}$ and nitrogen digestibilities will be considered in the general discussion because of their greater contribution to the diet in comparison with ether extract.

TABLE 3. Mean values for apparent digestibility of nutrients of lambs given graded amounts of molasses in place of dietary maize.

\begin{tabular}{|c|c|c|c|}
\hline \multirow[b]{2}{*}{ Apparent digestibility \% } & $\begin{array}{l}\text { Ration A } \\
\text { molasses }\end{array}$ & $\begin{array}{c}\text { Ration } B \\
14 \% \text { molasses }\end{array}$ & $\begin{array}{c}\text { Ration C } \\
26 \% \text { molasses }\end{array}$ \\
\hline & & & \\
\hline Dry matter(DEt) & 70.4 & 62.9 & 56.8 \\
\hline Organic matter(OK) & 72.4 & 62.7 & 58.0 \\
\hline Nitrogen $(N)$ & 67.6 & 58.5 & 72.4 \\
\hline Ether Extract(EE) & 85.6 & 57.9 & 57.5 \\
\hline Crude Pibers(CF) & 53.3 & 38.8 & 29.7 \\
\hline Sotuble cerbonyarrates & 76.1 & 73.0 & 69.5 \\
\hline
\end{tabular}

Carcass characteristics and slaughter data

Mean values with their SE for dressing percentages and slaughter data are presented in Tables 4 and 5.

Egypt. J. Anim. Prod. 21, No. 2 (1981) 


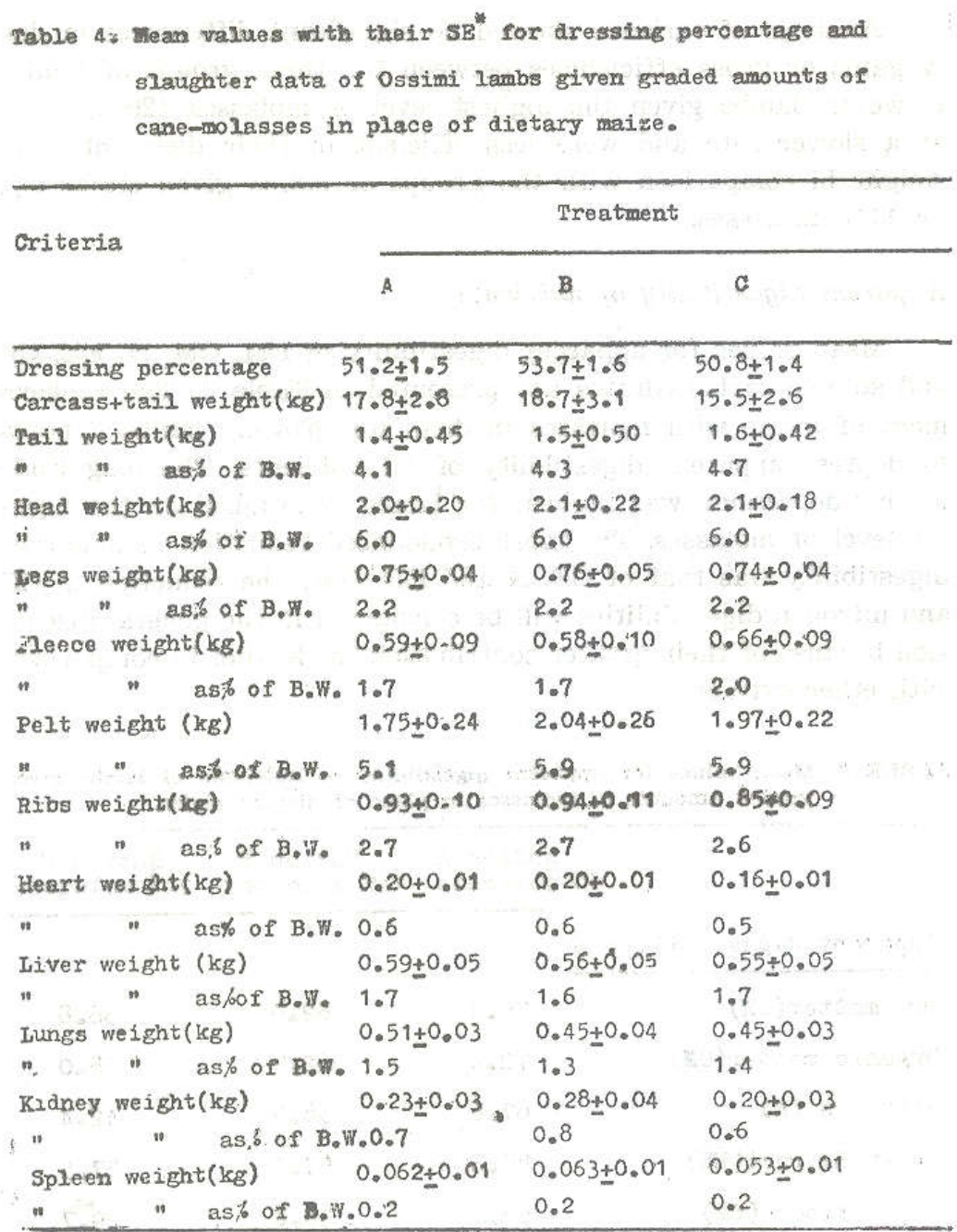

U. $\mathrm{S}_{0}$ - Standard Error:

Statistical analysis showed that the replacement of maize with different levels of molasses had no significant effect on dressing percentage or other slaughter data. However, lambs given the medium level of molasses appear to have slightly higher dressing percentage than the other two groups of lambs. Also lambs given the

Egypt. J. Anim, Prod. 21, No. 2 (1981) 


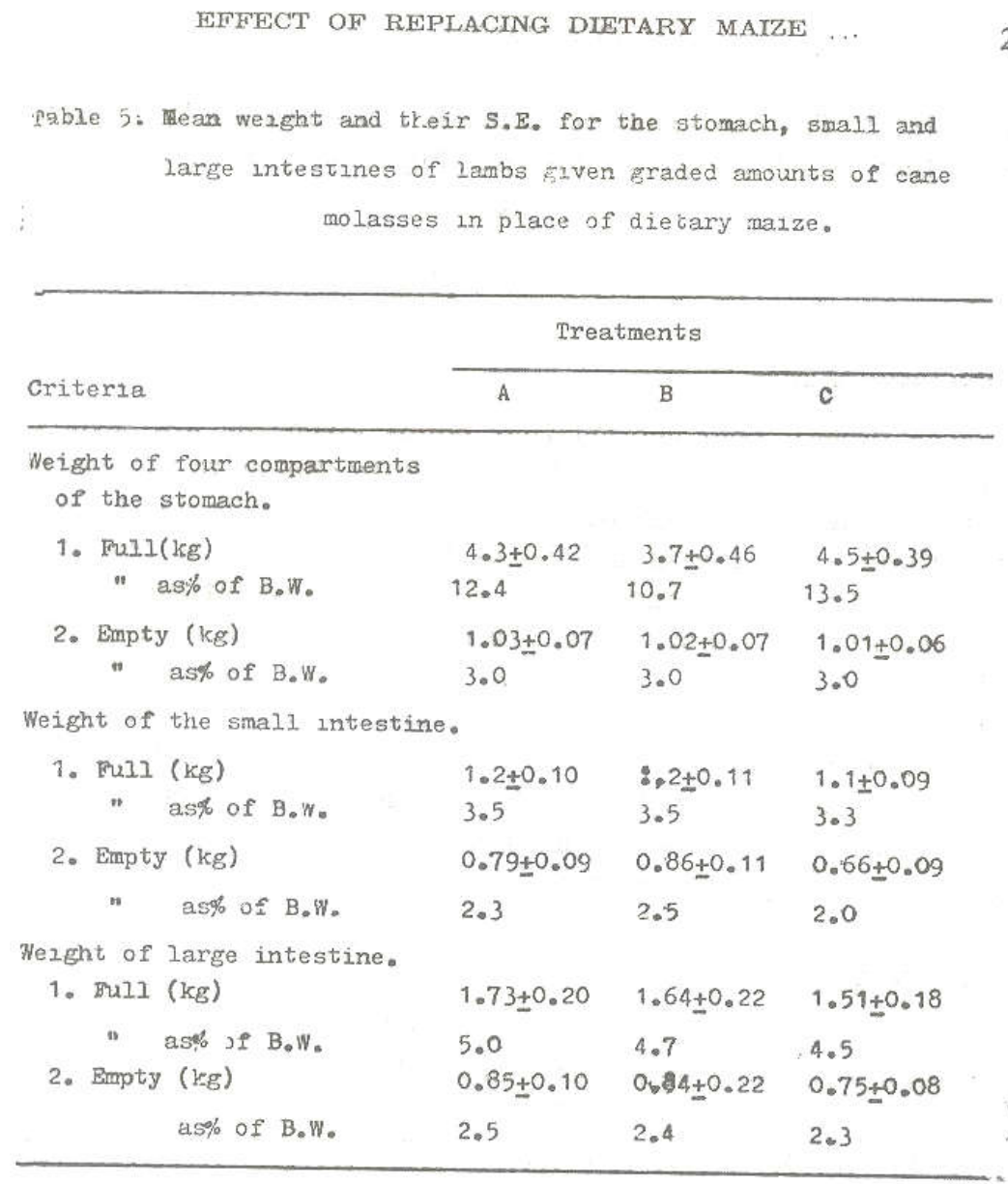

highest level of molasses had the lowest dressing percentage values. They had however, the highest tail weight either in absolute terms or expressed as a percentage of body weight.

The inclusion of cane-molasses up to the levels used in this experiment had no significant effect on the weights of the different parts of the digestive tract. Similar trend was recorded when these parts were related to live weight.

\section{D is cus sion}

The present results showed that cane-molasses can be included in lamb diets up to $26 \%$ of the DM with no palatability problems 
encountered. The quantities of molasses consumed/lamb/day were about $152 \mathrm{~g}$ and $305 \mathrm{~g}$ on the low and high levels of molasses respectively. These results were on agreement with those of Jordan and Hanke (1958), who reported that lambs can consume up to $500 \mathrm{~g}$ molasses/head/day with no acceptability problems.

\section{Lamb performance}

The growth trial showed that lambs given the low level of molasses ( $14 \%$ in the DM) performed nearly similar to the control group in terms of daily gains and gross efficiency (Table 2). However, those given the high level of molasses ( $26 \%$ in the DM), grew at a slower rate and utilized their diets less efficiently than the other two groups of lambs. These results suggested that, when included in the diets up to $14 \%$ in the DM, molasses appear to have no adverse effects on lamb performance. Merion et al. (1965) and Zorrilla and Merino (1972), found that lambs performed satisfactorily on diets containing 10 to $20 \%$ molasses. When the level of molasses was increased from 20 to 30 or $40 \%$ in the diet, lamb performance depressed greatly.

Nutrients digestibility

The results of the digestibility trials showed that apparent digestibility of most nutrients decreased as the level of molasses increased from 0 to 14 or $26 \%$ in the DM (Table 3). This reduction was most pronounced for $\mathrm{CF}$ and $\mathrm{N}$ digestibilities. To explain the reason (s) for the reduced digestibility with molasses, it is reasonable to assume that both the physical form and the type of carbohydrate have been altered when maize was replaced by molasses. Both factors may have altered the type of rumen fermentation. Orskov et al. (1974), showed that feeding whole barley grains to early weaned lambs was superior in terms of nutrients digestibilities to ground grains. The rumen $\mathrm{pH}$ was considerably higher with whole than with ground grains (6.4 vs 5.4). Similar situation may have occurred in the present study, by feeding molasses in place of maize. Thus molasses may have been fermented more rapidly than maize, leading to an early fall in rumen $\mathrm{pH}$. The reduced rumen $\mathrm{pH}$ may have inhibited the activity of cellulytic bacteria thus reducing DM, OM, and CF digestibilities (see Orskov et

Egypt. J. Anim. Prod. 21, No. 2 (1981) 
al., 1974). Martin and Wing (1966), found that inereasing the level of molasses from 6 to $18 \%$ in rations for fattening steers depressed digestibilities of DM, cellulose and energy.

The type of dietary carbohydrates, has been also found to affect the pattern of rumen fermentation. Marty and Sutherland (1970), Marty and Henderickx (1973) and Orskov (1975), reported that the inclusion of high levels of glucose or sucrose in the diets tend to enhance a butyric acid type of fermentation. Diets with high levels of starch usually characterized with high propionic acid type of fermentation. The former type of fermentation is likely to be similar to that of molasses containing diets. The production of butyric acid may have altered the ratio of 2.25 to 3.0 of non-glucogenic to glucogenic metabolites entering intermediary metabolism and needed for optimum energy utilization in case of growth and fattening as suggested by Orskov (1975).

It is also possible that a secondary type of fermentation may have occurred in the rumen with molasses leading to the conversion of VFA's to $\mathrm{CO}_{2}$ and methane, thus reducing energy availability to the animal (Rowe et al., 1979).

Nitrogen digestibility decreased with increasing level of molasses in the diet. If it is assumed that varying quantities of molasses have escaped rumen fermeratation, it will only be formented in the have escaped rumen fermentation, it will only be fermented in the intestine (Dollar and Porter 1957, Huber et al., 1961; Siddons, 1968; and Orskov et al., 1972).

Fermentation of molasses in the lower tract may have increased faecal nitrogen (Orskov and Foot, 1969), thus leading to an under estimation in nitrogen digestibility. Along with the possible effects of molasses on rumen metabolism may be sufficient to explain the reduced lamb performance on the high level of molasses.

The present results showed that the levels of molasses used in this experiment had no significance effect on dressing percentage or other slaughter data. These results were possibly expected since such data are usually more affected by differences in levels of feeding, protein and energy levels (see Soliman, 1971).

Egypt. J. Anim. Prod. 21, No. 2 (1981) 
Finally, it may be concluded that molasses can be successfully used in lamb diets up to at least $14 \%$ in the DM, with no adverse effects on lamb performance. Work in progress is being undertaken as examine the possibility of using either buffers or NPN sources or both diets containing high levels of molasses.

\section{$R$ ef erences}

Abou-Raya, A.K. (196\%) «Animal and Poultry Juding» Ist. Edit. Dar El-Maaref, Egypt.

A.O.A.C. (19\%0) Association of Official Chemists. Official Methods of analysis 11th Ed. Washington, D.C.

Clark, J., Geerken. C.M., Prestron, T.R. and Zamora, A. (1973) Molasses as an energy source in low fibre diets for milk production. 3. The effect of varying the molasses : grain ration in a low fibre basal diet. Cuban. J. Agric. Sci $\%, 156$

Dollar, A.M. and Porter, J.W.G. (195\%) Utilization of carbohydrates by the young calf. Nature 98,45 .

Huber, J.T., Jacobson, N.I., Allen, R.S. and Hartiman, P.A. (1961) Digestive enzyme activities in the young calf. J. Dairy Sci. 44, 1494.

Kuektasv, Ex, Cadeno, G. and Bullis, D. (1975) The effect on milk production of a feed supplement containing different levels of Sugar cane molasses and urea. J. Dairy Sci. 3\%, 69 (Abr.).

Jordan, R.M. and Hanke, H.W. (1958) The effect of feeding a molasses urea-alcohol supplement to fattening lambs. J. Anim. Sci. 1\%, 1162 (Abst.).

Losado, H., Martin, J.L., Willis, M.B. and Preston, T.R. (19\%3) Effect of castration and housing system on growth and carcass composition of, $\mathrm{F}_{1}$ Holstein $\mathrm{X}$ Santo Gertruscis bulls and molasses based diets. Cuban. d. Agric. Sci. 7, 191.

Martin, J.R. (Jr) and Wing, J.M. (1966) Effect of molasses level on digestibility of high coneentrate ration and on molar proportions of volatile fatty acids in the rumen of steers. J. Dairy Sci. $49,846$. 
Marty, R.J. and Henderickx (1973) Study on the buffering properties of the rumen fluid of sheep fed a higher sugar cane molasses diet. Cuban, J. Agric. Sci. 7, 191.

Marty, R.J. and Sutherland, T.M. (1970) Changes in sucrose and lactic acid metabolism in the rumen during adaptation to a high molasses diet.Rev. Cuban Cience. Agric. (eng. ed). 4,

Merino, H., Raun, N.S. and E. Gonzalez, E. (1966) J. Anim. Sci. 24, 897 (Abst.).

Nour, A.M., El-Shazly, IK; Abou Akkada, A.R., Naga, M.A. and Abaza, M.A. (1979) Effect of various sources of energy on urea utilization in vitro. Alex. J. Agric. Res. 26, 309.

Orskov, $\mathbf{E} . \mathbf{R}$. (19\%5) Manipulation of rumen fermentation for maximum food utilization. Wld. Rev. Nutr. Diet. 22, 152.

Orskov, E.R. and Fraser, C. (1972) The effect of type of rumen fermentation and digestibility of feeding whole as opposed to processed barley for sheep. Proc. Nutr. Soc. 31, 101 A.

Orskov, $\mathbb{E} . \mathbb{R}$., Fraser, C. and Gordon, J.G. (19\%4) Effect of processing of cereals on rumen fermentation, digestibility, rumination time, and firmness of subcutaneous fat in lambs. Br. J.
Nutr. 32, 59.

Orskov, E.R., Mayes, R.W. and Mann, S.O. (1972) Postruminal digestion of sucrose in sheep Br. J. Nutr. 28, 425.

Orskov, E.R. and Meryl, H. Foot. (1969) The influence of caecol starch infusion in sheep and faecal out-put of nitrogen, starch and dry matter. Proc. Nutr. Soc. 28, $31 \mathrm{~A}$.

Rowe, J.B., Marion, L, Laughnam, Nolan, J.V. and Leng, R.R. (1979) Secondary fermentation in the rumen of a sheep given a diet based on molasses. Br. J. Nutr. 41, 393.

Siddons, R.C. (1968) Carbohydrase activities in the bovine digestive tract. Biochem. J. 108, 839. 
Snedecor, G.W. and Cochran, W.G. (196\%) "Statistical Methods». 6th Edit. pp. 258. The Iowa State University Press, Ames, Iowa, U.S.A.

Soliman, H.S. (19\%1) Allowances of starch and protein for fattening lambs. M.Sc. Thesis, Fac. Agric. Univ. of Ain-Shams.

Tommi, R. (1963) Allowances and rations for farm animals Sel. Khoz., Izdot, Moscow.

Zorrillar, J.M. and Merino, Z.H. (1970) Rations with two levels of molasses and two levels of supplements of $\mathrm{k}$ and $\mathrm{Zn}$ for feeding ruminants. Tecnica pecuaria in Mixco, 14, 5-10. Cited after N.A. and R. 1972, 42, 339.

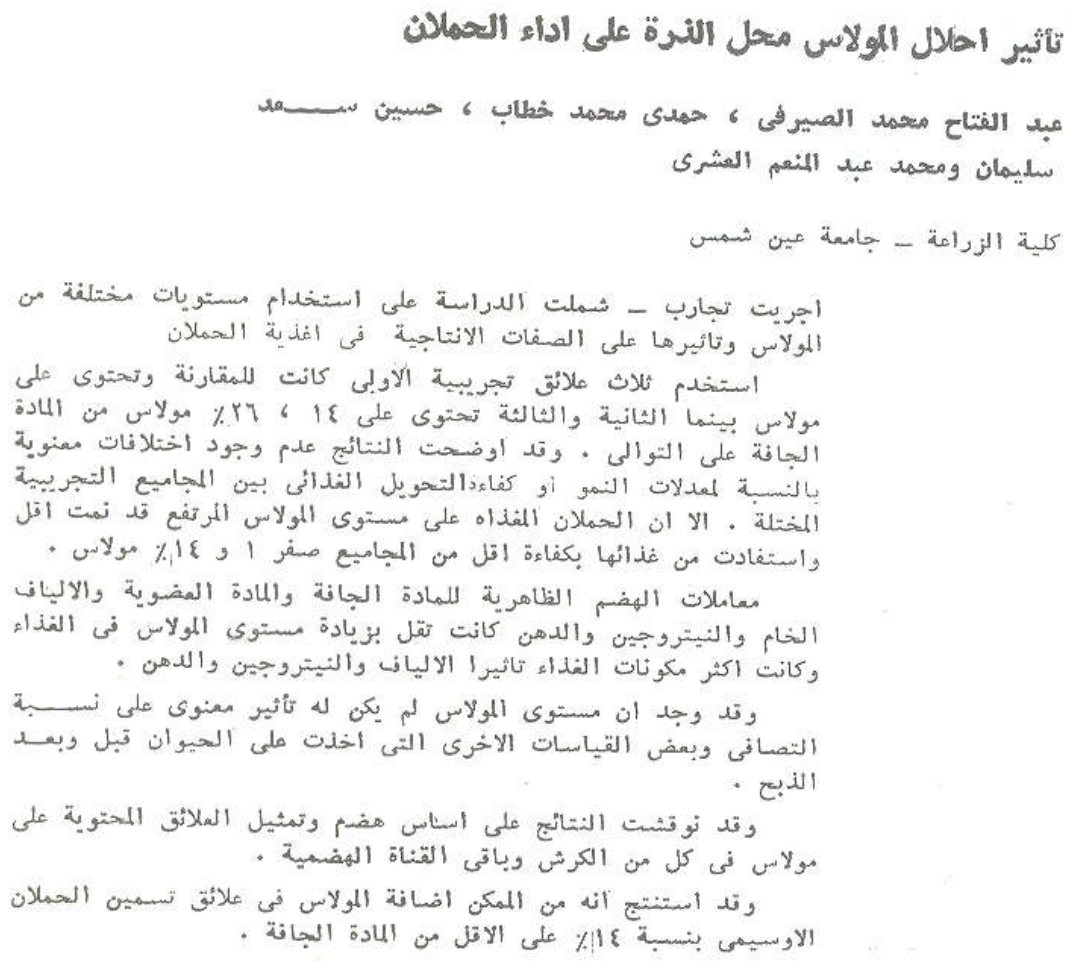

Egypt. J. Anim. Prod. 21, No. 2 (1981) 